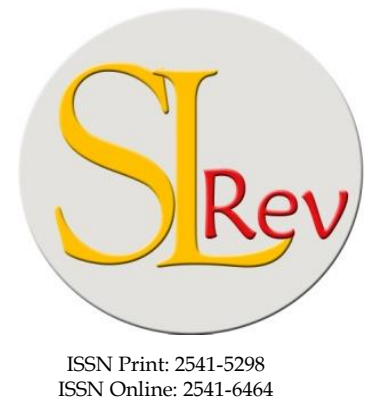

ISSN Online: 2541-6464

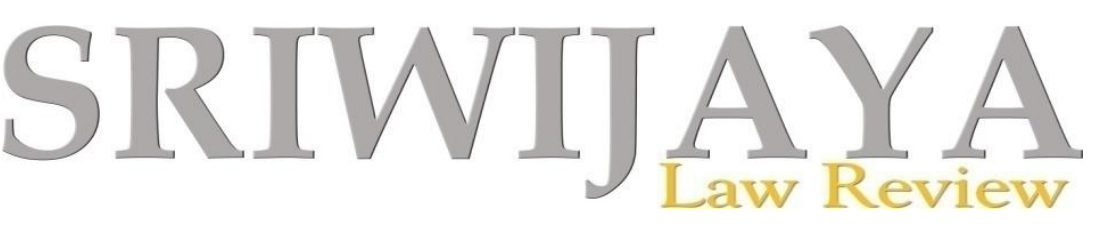

Editorial Office: Faculty of Law, Sriwijaya University, Jalan Srijaya Negara,

Palembang, South Sumatra 30139, Indonesia.

Phone: +62711-580063Fax: +62711-581179

E-mail: sriwijayalawreview@unsri.ac.id| sriwijayalawreview@ gmail.com

Website: http://journal.fh.unsri.ac.id/index.php/sriwijayalawreview

\title{
Philosophical Foundation of Chemical Castration for Offenders of Sexual Violence Against Children
}

\author{
Henny Yuningsih $^{\mathrm{a}}$, I Nyoman Nurjaya ${ }^{\mathrm{b}}$, Prija Djatmika ${ }^{\mathrm{b}}$, and Masruchin Ruba' ${ }^{\mathrm{b}}$
}

a Faculty of Law, Universitas Sriwijaya, Indonesia. E-mail: henny_yuningsih@yahoo.com

b Faculty of Law, Universitas Brawijaya, Indonesia. E-mail: nurjayai@yahoo.com

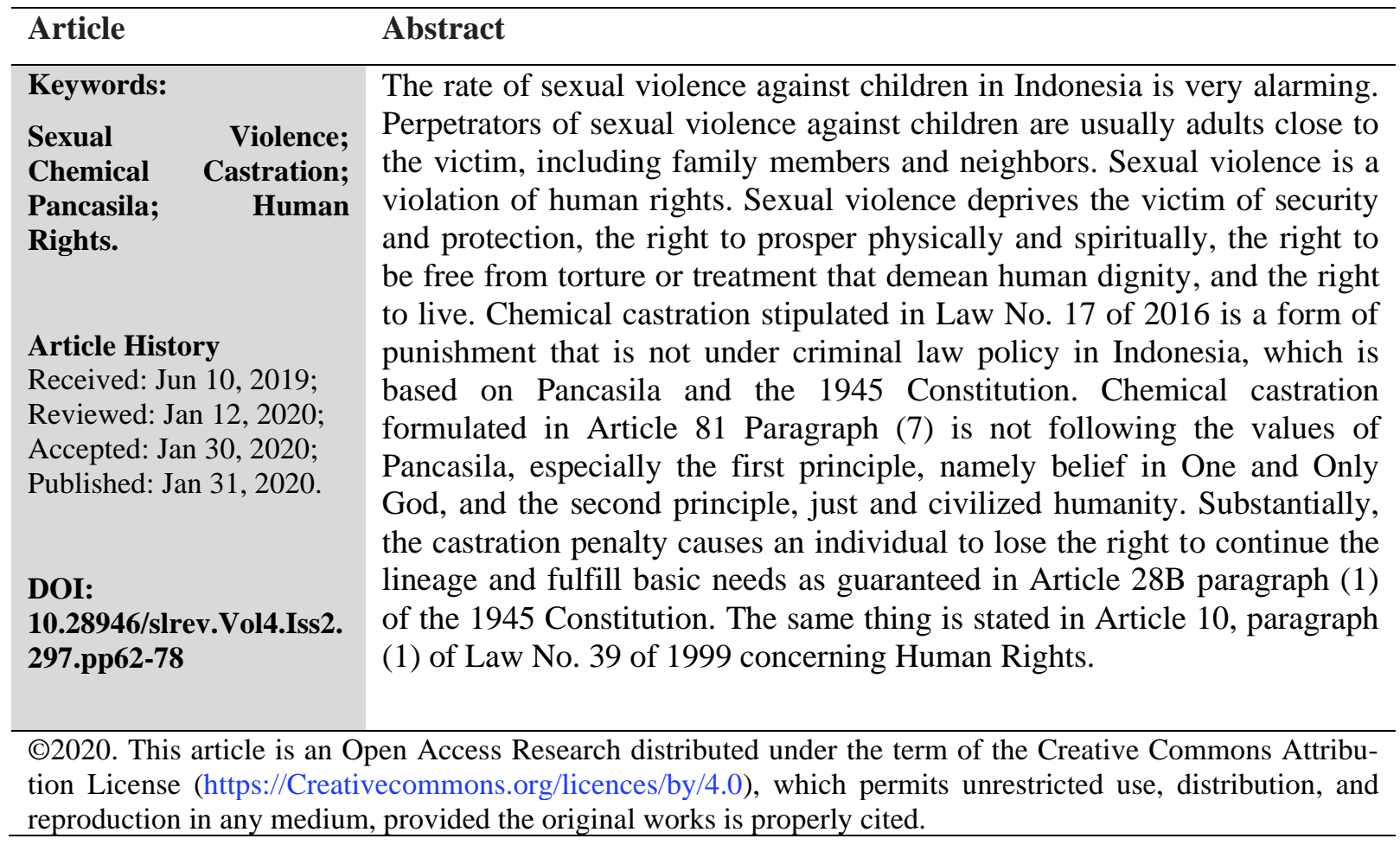

\section{INTRODUCTION}

The Unitary State of the Republic of Indonesia is a legal state with a worldview based on Pancasila, the state's philosophy. As such, the state is run based on values contained in Pancasila: religiosity, humanity, unity, democracy, and justice. It is as stated in the fourth paragraph of the "Preamble of the 1945 Constitution of the Republic of Indonesia (the 1945 Constitution)":

"Pursuant to which, in order to form a Government of the State of Indonesia that shall protect the whole
people of Indonesia and the entire homeland of Indonesia, and in order to advance general prosperity, to
develop the nation's intellectual life, and to contribute to the implementation of a world order based on
freedom, lasting peace and social justice, Indonesia's National Independence shall be laid down in a
Constitution of the State of Indonesia, which is to be established as the State of the Republic of Indonesia 
with sovereignty of the people and based on the belief in the One and Only God, on just and civilized humanity, on the unity of Indonesia and on democratic rule that is guided by the strength of wisdom resulting from deliberation/representation, so as to realize social justice for all the people of Indonesia."

Pancasila values in the 1945 Constitution, which had been amended since 1999, guarantees citizens' human rights and enforce efforts to respect, protect, fulfill, and promote human rights while providing legal protection. It is apparent in the results of the amendments to the 1945 Constitution, namely the addition of Chapter XI dedicated to Human Rights, regulated in Article 28 A to Article $28 \mathrm{~J}$. According to the United Nations (UN) declaration, human rights are the goals and means of development. People's participation in development is the realization of rights to development. International and national development institutions also must place human rights as one of the main focuses of development. However, the phenomenon of human rights must be observed wisely, because, in an individualist society, there is a tendency to demand excessive implementation of human rights. Demanding human rights to be implemented excessively means violating the same human rights that others have. ${ }^{1}$

According to paragraph IV the Preamble of the 1945 Constitution, one of the state goals is to protect all citizens without exception. The context of legal protection can be applied in all aspects of life to realize that mandate. The development and modernization of aspects of life affect people's behavior, which is evident in the crimes related to sexual deviance.

Children are often victims of crimes committed by people they know. As formulated in the provisions of Article 1(16) of Law Number 35 of 2014 concerning Amendment to Law Number 23 of 2002 concerning Child Protection which states that: "violence is every act against a child which results in physical, psychological, sexual, and/or neglectful misery or suffering, including threats to commit acts, coercion, or deprivation of liberty against the law."

Currently, child abuse is increasing year by year. According to the data compiled by the National Commission for Child Protection and Information Center in 2010-2015, there were 2,046 complaints in 2010, of which $42 \%$ were sexual violence. In 2011 there were 2,426 cases, of which $52 \%$ were sexual violence. Then in 2012, there were 2,723 complaints, of which $58 \%$ were sexual violence. In 2013, there were 3,339 cases, of which $62 \%$ were sexual violence. Then in 2014, there were 3,762 cases, of which 52\% were sexual violence. 2015 witnessed an increase in complaints with 1,725 cases, of which $48 \%$ were sexual violence.

Sexual violence against children is very concerning today and is one of the crimes against humanity. This concern is evident in the increase in sexual violence against children. "Data from the Child Protection Agency shows that until now, there were 21,689,797 cases of violations of children's rights, and $58 \%$ of them were sexual violence. Meanwhile, according to data from the National Commission for Child Protection, there were 22 million children who experienced violence in 2010-2014, and $42 \%$ of them were sexual violence. These statistics show that the number of victims of sexual violence against children is high. The nation will lose its future generations if they ignore these cases."

Satjipto Rahardjo, Hak Asasi Manusia Dalam Masyarakatnya (Bandung: Refika Aditama, 2005).

Komnas Ham, “Komnas-Ham-Perppu-Tentang-Penghukuman-Kebiri-Untuk-Tidak-Diterbitkan,” 2017, http://www.komnasham.go.id/kabar-latuharhary/komnas-ham-perppu-tentang-penghukuman-kebiri-untuktidak-diterbitkan. 
In 2019 the Mojokerto District Court handed down a criminal offense against a sexual violence offender against a child by chemical castration. It is as regulated in Article 81 (7) Law Number 17 of 2016. The judge's decision in the form of a chemical castration act was the first decision implemented in Indonesia against the perpetrators of sexual crimes against children. The Mojokerto District Court stated that Defendant Aris was guilty of violence and forced the child to have intercourse by giving a sentence of 12 years in prison and a fine of Rp 100 million in 6-month confinement. The panel of judges also imposed an additional criminal form of chemical castration on Aris. The Surabaya High Court, the Surabaya High Court Judge, also upheld the Mojokerto District Court's decision. The sentence was stated in the Decision of PT Surabaya number 695/PID.SUS/2019/PT SBY, dated July 18, 2019. Thus, the castration penalty, as stipulated in Article 81 paragraph (7) of Law No. 17 of 2016, when linked to human rights, violates two principles that are the mandate of reform: human rights and democracy. In substance, the castration penalty causes an individual to lose the right to continue the lineage and fulfill basic needs guaranteed in "Article 28B paragraph (1) of the 1945 Constitution." "Article 10 paragraph (1) of Law No. 39 of 1999 concerning Human Rights" states the same thing. According to Amnesty International, the implementation of the castration penalty in the form of chemical injections violates international law, as regulated in Article 7 of the International Covenant on Civil Political Rights. Indonesia itself has ratified the "International Covenant on Civil and Political Rights" (ICCPR), on October 28, 2005, through "Law of the Republic of Indonesia Number 12 of 2005 concerning Ratification of the International Covenant on Civil and Political Rights."

On the difference between punishment and treatment, Hazewinkel Suringa stated that "punishment intends to cause suffering to a perpetrator of a criminal act, while a treatment, according to criminal law, does not have any intention to cause suffering."3

Punishment is very responsive to an act, while treatment is more anticipatory towards the perpetrators of these acts. ${ }^{4}$ Punishment focuses on the actions of an individual through the imposition of suffering (so that the individual concerned becomes deterrent). In contrast, treatment focuses on efforts to help the perpetrator to change. Thus, punishment emphasizes retribution. It means intentionally causing suffering to the perpetrator. On the other hand, treatment intends to protect the public and foster or care for the perpetrators. ${ }^{5}$

The Government shows their commitment to protecting the rights of children as victims of sexual violence, as stipulated in Article 28 B paragraph (2) of the 1945 Constitution, ${ }^{6}$ by ratifying "Government Regulation in Lieu of Law (Perppu) No. 1 of 2016 concerning the Second Amendment to Law No. 23 of 2002 concerning Child Protection." This Perppu focuses on the increase of the severity of punishment and the provision of additional punishments for perpetrators of crimes and or sexual violence against children as prevention and rehabilitation efforts and to give deterrent effects. "Government Regulation in Lieu of Law No. 1 of 2016" has been ratified into "Law No. 17 of 2016 concerning Stipulation of Government Regulation

P.A.F. Lamintang and Theo Lamintang, Hukum Penitensier Indonesia (Jakarta: Sinar Grafika, 2012).

4 M. Sholehuddin, Sistem Sanksi Dalam Hukum Pidana Ide Dasar Double Track System Dan Implementasinya (Jakarta: Raja Grapindo Persada, 2003).

5 Sholehuddin.

6 "The 1945 Constitution of the Republic of Indonesia" (n.d.). 
in Lieu of Law No. 1 of 2016 concerning the Second Amendment to Law No. 23 of 2002 concerning the Protection of Children Becomes Law." One of the changes to the provisions in Law No. 17 of 2016 is Article 81 paragraph (7) which states "that the perpetrators referred to in paragraph (4) ${ }^{7}$ and paragraph $(5)^{8}$ can be subjected to acts of chemical castration and installation of electronic detectors." 9

According to that provision, castration is one of the punishments in the Indonesian criminal law. It has just been implemented based on Government Regulation in Lieu of Law No. 1 of 2016 issued by the President of the Republic of Indonesia where this Regulation has been ratified into "Law No. 17 of 2016 concerning Stipulation of Government Regulation in Lieu of Law No.1 of 2016 concerning the Second Amendment to Law No. 23 of 2002 concerning the Protection of Children Becomes Law." Thus, the castration penalty, as stipulated in Article 81 paragraph (7) of Law No. 17 of 2016, when linked to human rights, violates two principles that are the mandate of reform: human rights and democracy. ${ }^{10}$ In substance, the castration penalty causes an individual to lose the right to continue the lineage and fulfill basic needs guaranteed in "Article 28B paragraph (1) of the 1945 Constitution."11 "Article 10 paragraph (1) of Law No. 39 of 1999 concerning Human Rights" states the same thing. ${ }^{12}$ According to Amnesty International, the implementation of the castration penalty in the form of chemical injections violates international law, as regulated in Article 7 of the International Covenant on Civil Political Rights. ${ }^{13}$ Indonesia itself has ratified the "International Covenant on Civil and Political Rights" (ICCPR), on October 28, 2005, through "Law of the Republic of Indonesia Number 12 of 2005 concerning Ratification of the International Covenant on Civil and Political Rights."

In addition to the ICCPR, Indonesia has also ratified "Convention against Torture and Other Cruel, Inhuman or Degrading Treatment or Punishment," into "Law No. 5 of 1998 concerning Ratification of Convention against Torture and Other Cruel, Inhuman or Degrading Treatment or Punishment." This convention opposes all forms of torture or other cruel punishments. Thus, implementing chemical castration through law is cruel, inhuman, and degrading punishment.

Anything "cruel" has destructive connotations. Humans are forbidden to inflict cruelty on animals, let alone to humans. When cruel punishment is imposed on humans, the human being has been hit by multiple calamities: "punishment" and "cruelty." Due to the severity of these punishments, the cruel sentencing of criminal perpetrators has been classified as human rights violations. ${ }^{14}$ Thus, the implementation of the castration penalty contradicts human rights as contained in the 1945 Constitution and the Human Rights Law. The question is, what is the

\footnotetext{
"The Law No. 17 of 2016 Concenring Amendment to Law Number 10 of 1995 on Customs" (n.d.).

8 The Law No. 17 of 2016 Concenring Amendment to Law Number 10 of 1995 on Customs.

The Law No. 17 of 2016 Concenring Amendment to Law Number 10 of 1995 on Customs.

10 Fitri Wahyuni, "Hukuman Kebiri Terhadap Pelaku Tindak Pidana Pemerkosaan Anak Dan Kaitanannya Dengan Hak Asasi Manusia,” Jurnal Hukum Dan Peradilan 6, no. 2 (2017): 279-96.

11 The 1945 Constitution of the Republic of Indonesia.

12 "The Law No. 39 of 1999 Concerning Human Rights" (n.d.).

13 "International Covenant on Civil Political Rights," n.d.

14 Munir Fuady and Sylvia Laura L. Fuady, Hak Asasi Tersangka Pidana (Jakarta: Prenada Media Group, 2015).
} 
philosophical foundation for regulating chemical castration against perpetrators of sexual violence against children?

\section{RESEARCH METHOD}

This research is normative legal research. According to Soerjono Soekanto and Sri Mamuji, "normative legal research is legal research carried out using methods that examine library materials or secondary data only." 15 This research used the Statute Approach, Conceptual Approach, and Historical Approach. The sources of data in this research include primary legal material, secondary legal materials, and tertiary legal materials. Techniques for collecting legal materials in this research include library studies and using information technology (internet). The analysis in this research was "prescriptively analytical, aiming to produce prescriptions about what should be the essence of legal research that adheres to the character of law as applied science. ${ }^{16}$

\section{ANALYSIS AND DISCUSSION}

\section{Definition and History of Castration}

According to the Great Dictionary of the Indonesian Language, castration is the removal of testicles to prevent the castrated person from producing semen or sperm. Castration is a surgical and or chemical procedure that aims to eliminate testicular function in males or ovarian function in females. According to the Dictionary of Health, castration is the surgical removal of the testicles as a reproductive organ, to lower or eliminate sexual urges in someone.

Castration sanction is a rule or set of laws regulating castration. Castration itself is a medical procedure that removes the testicles, penises, and male external sex organs. Castration referred to here is the legal consequence of the crime of sexual violence against children, referring to Law No. 17 of 2016 concerning Stipulation of Government Regulation in Lieu of Law No. 1 of 2016 concerning the Second Amendment to Law No. 23 of 2002 concerning Child Protection Becomes Law. Changes to the new provisions are contained in Law No. 17 of 2016 concerning Stipulation of Government Regulation in Lieu of Law No. 1 of 2016 concerning the Second Amendment to Law No. 23 of 2002 concerning Child Protection Becomes Law.

As one of the punishments in the Indonesian criminal law, the castration penalty has just been implemented based on Law No. 17 of 2016 concerning the Stipulation of Government Regulation in Lieu of Law No. 1 of 2016 concerning the Second Amendment to Law No. 23 of 2002 concerning Child Protection Becomes Law. The punishment intends to prevent the crime of sexual violence against children, but it is clear that the castration penalty aims to make the offender becomes deterrent. There are two types of castration: chemical castration and physical castration (surgery). Physical castration involves excising the external sex organs to lower the testosterone significantly. Meanwhile, chemical castration is to insert antiandrogen into the body through injections or pills.

\footnotetext{
15 Soerjono Soekanto and Sri Mamuji, Penelitian Hukum Normatif (Jakarta: Rajawali, 1985).

16 Purnadi Pubacaraka and Soerjono Soekanto, Perihal Kaedah Hukum (Bandung: Alumni, 1978).
} 
There are two forms of castration actions: excision or chemical injection, known as chemical castration. Chemical castration is the act of inserting antiandrogen, either through pills or injections, into the body of an offender of sexual violence in order to lower the testosterone. A journal entitled California's Chemical Castration Law: Model for Massachusetts? explains that "chemical castration is a medical treatment that uses antihormonal drugs to block the release of hormones, consequently reducing testosterone levels significantly and sex drive in men." 17

Throughout the history of human civilization, castration was carried out for various purposes. Eastern Mediterranean castrated animals to have more female cattle than male cattle. In Egypt in 2,600 BC (BC), castrated slaves had higher value because they were considered more diligent and obedient to their masters. Similar actions occurred to slaves in Greece around 500 BC (BC), guardians of the Persian harem, and Chinese treasurers and imperial officials. ${ }^{18}$

Castration on humans is not a new phenomenon. In the 20th century, castration was carried out as a punishment for rape or harassment. Europe practiced castration of sex offenders in the early 20th century. The Danish people pioneered the first law in 1929, ratifying medical penalties for sexual offenders. After that, Germany (1933), Norway (1934), Finlandian (1935), Estonia (1937), Iceland (1938), Latvia (1938), and Sweden (1944) also started to impose similar penalties. The castration penalty in Europe aims to eliminate sexual urges, which are believed to be the etiological factor of sexual violence. ${ }^{19}$

Surgical castration (testicular pulpectomy or bilateral orchiectomy) is an irreversible procedure that involves removing the testicles, which produce male hormones. The procedure is relatively simple: make a small incision in the scrotum and remove the testicles. Then insert prostheses into the scrotum to prevent it from appearing empty after the testicles have been removed. It is assumed that the surgical removal of the sex glands will decrease sex hormones in the body, which results in the loss of sex drive. ${ }^{20}$

Surgical castration causes permanent side effects, such as excessive sweating, loss of body hair and facial hair, weight gain, softening of the skin, loss of protein, augmentation of pituitary functions and keratin in urine, and reduction of calcium in bones within a specified period. Meanwhile, psychological side effects include depression, suicidal tendencies, emotional instability, and indifference to life. ${ }^{21}$

Throughout history, castration has been classified as one of the unusual punishments. In its implementation, castration has two methods. The first is surgical castration or physical castration, which involves cutting the testes in a surgery. The second method is by injecting particular substances.

17 John S. Murray, “California’s Chemical Castration Law: A Model For Massachusetts?” 24, no. 279 (1998): 732.

18 Dkk Supriyadi Widodo Eddyono, Menguji Euforia Kebiri (Jakarta: ICJR Mappi FH UI, 2016).

19 Linda E. Weiberger et al., "The Impact of Surgical Castration Risk among Sexually Violend Predatory Offenders," The Journal of the American Academy of Psychiatry and the Law 33, no. 1 (2005): 16-36.

20 Vioslay Stojanovsky, Surgical Castration Of Sex Offenders and 1st Legality: The Case Of the Czech Republic (Masarykiana Brunensis University, n.d.).

21 Stojanovsky. 


\section{Chemical Castration According to Pancasila}

The state has the authority to regulate the lives of the people. In the case of sexual violence against children, the government and the People's Representative Council respond by formulating and stipulating that the provisions of chemical castration in Law No. 17 of 2017 is not in line with Indonesian legal policy. In Indonesian legal policy, stipulating, substituting, or changing a policy contained in legislation must adhere to Pancasila because it is the legal foundation or constitution for Indonesia.

As the foundation and ideology of the State, Pancasila must be the paradigm (framework for thinking, source of value, and orientation in life) of the development of the law and all efforts to renew it. As the foundation of the state, Pancasila has a juridical connotation in the sense of giving birth to various legislations arranged hierarchically and rooted in Pancasila. Meanwhile, Pancasila, as an ideology, implies a socio-political program where the law is one of its tools and therefore, must also be derived from it. ${ }^{22}$

As the foundation and ideology of the State or as legal ideas and staatsfundamentalnorm, Pancasila must be the paradigm in every legal development and reform. Legal material or products can always change and be changed according to the times and changes in society because the law is not in a vacuum. Thus, the law, as a servant of community needs, must be updated so that it always fulfills the needs of the people it serves. In the continuous development and renewal of the law, Pancasila must remain to be the framework for thinking and the sources of value. ${ }^{23}$

As the paradigm of legal development, Pancasila has four principles that must be used as guidelines in the establishment and enforcement of the law in Indonesia. First, the law must protect all nations and guarantee the integrity of the nation. There are no laws that plant the seeds of disintegration. Second, the law must be able to guarantee social justice by providing special protection for the weaker groups. It is to prevent influential groups from exploiting the weaker groups in free competition. Third, the law must be made democratically while building democracy in line with nomocracy (government based on the rule of law). Fourth, the law must not discriminate against people based on any primordial bond and must encourage religious tolerance based on humanity and civilization. ${ }^{24}$

Efforts to renew legal order must continue to make Pancasila its paradigm. It is because Pancasila as the foundation, ideology, the idea of law, and fundamental norms of the State must be the orientation, the source of values, and the framework for thinking in any legal reform effort. The ineffectiveness of the law in playing its functions and roles in Indonesia today is not because Pancasila is an inappropriate paradigm. Instead, it is caused by deviations from Pancasila. In reality, there are no recommendations from any study to change or replace Pancasila as modus Vivendi. Instead, there are demands to reorganize legal order under Pancasila as its paradigm. The renewal of the law can reach the 1945 Constitution as fundamental law and all regulations under it. ${ }^{25}$

\footnotetext{
22 Moh. Mahfud MD, Membangun Politik Hukum, Menegakkan Konstitusi (Jakarta: PT. Raja Grafindo, Persada, 2010).

23 Moh. Mahfud MD.

24 Moh. Mahfud MD.

25 Moh. Mahfud MD.
} 
Paragraph IV of the Preamble of the 1945 Constitution ${ }^{26}$ explicitly affirms Pancasila as the philosophical foundation of the State. It means that the Indonesian people expect Pancasila to provide motivation, direction, and spirit to improve their lot and catch up with developed countries. In politics, Pancasila is seen as the state ideology and the philosophical foundation of the State. This statement holds a philosophical meaning, which is every aspect of the administration of the State must be following Pancasila.

As the philosophical foundation of the State, Pancasila has two interrelated meanings. First, Pancasila is the only State ideology, which acts as the primary foundation for the implementation of the State's ideas. The central point of these ideas is a just and prosperous society (both material and spiritual) in a just and civilized humanitarian framework based on religiosity, humanity, unity, and democracy. These ideas become the direction and goals of the State as formulated in the Preamble of the 1945 Constitution, especially in paragraph IV, which is the foundation, soul, and source of spirit for the administration of the State. Second, Pancasila is a moral foundation. The central point of State morality is religiosity, which contains God's teachings and human values. They give birth to natural law and ethical law as the foundations of Indonesia's legal philosophy and the rationale for regulating public order. In this sense, Pancasila is the highest legal idea that acts as the source of all legal sources in Indonesia. ${ }^{27}$

For Indonesia, Pancasila is the philosophy of the nation. Pancasila is Indonesia's soul and way of life. It is the truth. Soediman Kartohadiprojo argues that Pancasila is a way of life by stating, "The Indonesian way of life has been formulated in a solid form in a series of five principles called the Pancasila." Pancasila was consciously and intentionally placed in the Preamble of the 1945 Constitution as the philosophical foundation that underlies and inspirits the establishment of the provisions in the constitution. It means Pancasila also underlies and inspires life in Indonesia, including activities to determine and implement its legal policies. Therefore, due to the enactment of the constitution, the establishment and implementation of Indonesian legal system must be based on and inspired by Pancasila. ${ }^{28}$

By establishing Pancasila as the filosofische grondslag or rechtsidee or the idea of law, the establishment and implementation of the law cannot be separated from the values in Pancasila. Regarding the idea of Pancasila, Bernard Arief Shidarta stated that "in the present, Pancasila as 'base values' has become a reality. However, Pancasila as 'goals values,' only the religiosity principle and the unity principle that has become a reality, while other principles still have to be fought for." 29

Pancasila, as goal values, provides the foundation for the law, which is to protect humans. There are two means of protection. The first is passive (negative) protection by preventing arbitrary actions. The second is active (positive) protection by creating a democratic environment to ensure that every human being receives equal treatment.

\footnotetext{
26 The 1945 Constitution of the Republic of Indonesia.

27 Tongat, "Https://Ejournal.Fakultas Hukum Universitas Muhamadiyah Malang, Pancasila Sebagai Dasar Falsafah Negara Dan Makna Filosofisnya Dalam Pembaharuan Hukum Pidana Nasional," 2017.

28 Nyana Wangsa and Kristian, Hermeneutika Pancasila Orisinalitas Dan Bahasa Hukum Indonesia (Bandung: PT. Refika Aditama, 2015).

29 Kristian.
} 
Thus, all legal norms, legal institutions, and law enforcement in Indonesia should be based on Pancasila as goal values, in the form of a legal system that protects human beings. A system that prevents arbitrary actions and creates democratic conditions while still upholding a sense of justice in the sense that everyone has equal opportunity. ${ }^{30}$ According to Rudolf Stammler, the idea of law (rechtsidee) is like a star. A star helps people find their way with their light. Likewise, the idea of law must be able to direct the law in order to achieve the idea of society. The idea of society is a shared vision of society in life with the idea of law as the star, the way of life. As a system of philosophy, the principles in Pancasila are interrelated and inseparable. Each principle limits and enriches the meaning of other principles while presents as a unity. Thus, it is not justified to view Indonesian people from only one or two principles. ${ }^{31}$

In connection with this, Soediman Kartohadiprojo, as quoted by Widiada, stated that "to know better what is called Pancasila philosophy, we must find its substance. As a philosophy, Pancasila contains an integrated thought. So if we want to know the substance of Pancasila, then we must be able to find that integrated thought. We cannot find the substance of this thought just by giving meaning to each principle. The meaning that we give to each principle must have a logical relationship (logis verband) with each other. Thus, it becomes whole as a thought." 32

As a system of social philosophy, Pancasila has some essential components. The first is a value system. The second is Pancasila perspective on humans and the human perspective on nature. The third is the essence of humans, God, and the State. From the perspective of the value system, human beings are in a world of positive values (goodness, beauty, truth, and justice) and negative values (evil, falsehood, and sin). Each individual always has active or passive interaction with the world of values. ${ }^{33}$

Born from the authentic thoughts of Indonesia's founding fathers, Pancasila is the foundation of Indonesia's ideology based on the social conditions of the Indonesian people. Starting as an agrarian society that generally believes in God, the first principle, Belief in the One and Only God, is an element that can unite Indonesia. Thus, the State and the underlying laws must adhere to religiosity as the implementation of the first principle of Pancasila. ${ }^{34}$

The interpretation of Pancasila as an Indonesian perspective in dealing with punishment stems from the assumption that it provides a huge opportunity to formulate what is right and good for humans and Indonesia, which its validity can be accounted for contextually and operationally. In formulating the principles or abstract nature of Indonesian life, Pancasila is oriented in three human relationships: human relations with God, human relations with humans, and human relations with objects (including inorganic objects, plants, and animals). While the first principle gives an ontological framework (the nature of existence), the second principle gives a normative framework. These two principles allow the other three principles to develop

\author{
Kristian. \\ Kristian. \\ Kristian. \\ Kristian. \\ Soekarno, Filsafat Pancasila Menurut Bung Karno (Yogyakarta: Media Presindo, 2006).
}


as an operational framework in life as a nation (the third principle), as a state (the fourth principle), and as a community (the fifth principle). ${ }^{35}$

The principle Belief in One and Only God is the soul of Pancasila as it contains the obligation to follow God's teaching. Wreksosuhardjo said that the essence of God is Causa Prima since God is the first of all things, the ruler of nature's order, the origin of all things, deathless, the Almighty, the Perfect and the Good, must be respected and obeyed. ${ }^{36}$

The principle Belief in the One and Only God is a fundamental principle in Indonesia's legal system. Religiosity imbues and is imbued by the principle Belief in the One and Only God. This principle relates to the attributes of God, such as the Almighty, the Omnipotent, the Merciful, and others. Indonesian people know that they exist because of God. For a long time, this attitude acts as the foundation for harmonious religious life in Indonesia. ${ }^{37}$ It is clear that the principle Belief in the One and Only God provides a framework of values about humans as beings who believe in the power of God. That principle also gives Indonesian people guidance in determining what is right and wrong.

In criminal law, religiosity should give birth to principles that view humans as creatures more honorable than the others. As such, criminal law must not clash with humans' position. Likewise, punishments imposed on offenders must reflect respect for the principle Belief in the One and Only God. ${ }^{38}$

Based on the study of the first principle, chemical castration should also be examined from the perspective of the second principle. It is because the second principle, as a normative framework, contains an imperative to live or to act civilized and just. Civilized behavior reflects a spiritual attitude as a noble creature of God, while justice reflects human as a civilized creature. As a creature of God endowed with wisdom and freedom, every human being must be respected since all humans are equal. ${ }^{39}$

With this normative framework, Indonesian people can determine good and evil, which corresponds to the goals. That is, guided by the values of right and wrong, which stem from religious belief. The second principle provides a framework for formulating norms about good and evil based on the understanding of 'what is human.' It explains that humane is good while inhuman is evil. It also teaches Indonesian people to be fair and civilized to each other. ${ }^{40}$

The different orientation of the two types of penalties (punishment and treatment) has a connection with indeterminism, the philosophy that underlies the ideas for treatment. Indeterminism assumes that humans have free will, including when they commit crimes. Therefore, as the consequence of an individual's free choice, every penalty must aim for moral depravity and imposition of suffering on the offender. ${ }^{41}$

On the other hand, determinism assumes that all events and human behavior, both as individuals and a group, are determined by preexisting factors, including physical,

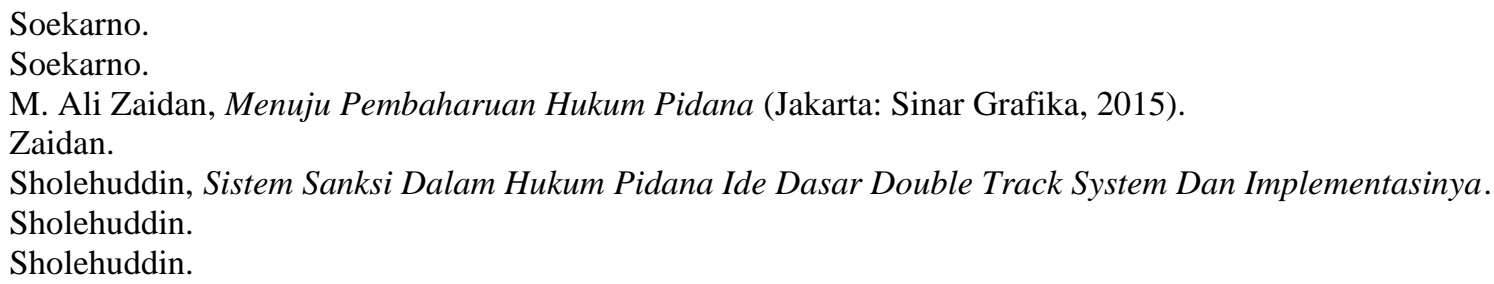


geographical, biological, psychological, sociological, economic, and religious factors. ${ }^{42}$ These factors determine the evil behavior of an individual or a group. Thus, each penalty can only be justified to rehabilitate the offender.

Differences in basic ideas between punishment and treatment can also be found in theories about the purpose of punishment. The substance of absolute theory or relative theory revolves around the differences in the basic idea of punishment and treatment.

For example, absolute theory (retributive theory) views punishment as retribution for the committed crime. It focuses on the action and the crime itself. The retributive theory looks at the past, focusing on the committed crimes. Sahetapy said that absolute theory views punishment as retribution for the offenders. Desiring for retribution is normal. However, it is a violent and emotional reaction, and thus irrational. ${ }^{43}$

According to absolute theory, punishment is imposed because the offender has committed a crime. Punishment becomes a fair retribution for losses caused by the offender. Hence, this theory is also known as the theory of proportionality. For this reason, punishment is morally justified. ${ }^{44}$

Relative theory (utilitarian theory) focuses on the three primary purposes of punishment: prevention, deterrence, and reformation. Preventative punishment aims to protect people by separating criminals from the community. Meanwhile, deterrence in punishment aims to cause fear of committing a crime. The goals of deterrence in punishment are divided into three categories: individual, public, and long-term goals. The individual goal is to prevent the offender from committing a crime again. Next, the public goal is to deter other people from committing a crime. Last, the long-term goal (long-term deterrence) is to maintain people's attitudes on punishment. This theory is often referred to as educative theory or denunciation theory. ${ }^{45}$

The relative theory considers punishment as a means to an end rather than retribution for the wrongdoing of the offender. It is useful for protecting the public and for achieving prosperity. From this theory emerges the purpose of punishment as a means of prevention, both special prevention aimed at the perpetrator and general prevention aimed at the community. The purpose of relative theory is to prevent and reduce crime. A punishment must be intended to change the behavior of criminals and other people who have the potential or tend to commit crimes. For this reason, this theory is more forward-looking.

According to Bentham's principle of utility, the penalty can be justified if the implementation crystallizes two main effects. First, the penalty must prevent future crimes. Second, the penalty provides satisfaction for the victim and others. This penalty is preventive. In other words, it prevents people from repeating their wrongdoings and fulfills the satisfaction of all people involved in the case. ${ }^{46}$ This theory is a limited, applied form of utilitarianism,

42 A. Mangunhardjana, Isme-Isme Dalam Etika Dari a Sampai Z (Yogyakarta: Kanisius, 1997).

43 J. E. Sahetapy, Suatu Studi Khusus Mengenai Ancaman Pidana Mati Terhadap Pembunuhan Berencana (Jakarta: CV. Rajawali, 1982).

44 Sholehuddin, Sistem Sanksi Dalam Hukum Pidana Ide Dasar Double Track System Dan Implementasinya.

45 Sholehuddin.

46 Frederikus Fios, "Keadilan Hukum Jeremy Bentham Dan Relevansinya Bagi Praktik Hukum Kontemporer," Humaniora III, no. 1 (2012): 299-309. 
which states that an action can be justified as long as it brings a good result for many people. The positive consequences of an action are the only criteria for justification.

Based on the previous explanation, the difference between punishment and treatment lies in whether or not there are elements of deprivation rather than the elements of suffering. Furthermore, treatment has an educational purpose. From the perspective of criminal theories, treatment is not retribution. Its sole aim is to protect the public from threats that can harm their interests. In short, punishment revolves around the idea of punishing the offender of an act, while treatment revolves around public protection. ${ }^{47}$

Chemical castration, as stipulated in Article 81 Paragraph (7) of Law No. 17 of 2016 to the offenders of sexual violence against children, is seen from the perspective of the second principle of Pancasila, just and civilized humanity. In other words, this case can be studied from the perspective of human rights. The study of human rights as a humans' universal right is included in the Universal Declaration of Human Rights. In Indonesia, human rights are regulated through the Republic of Indonesia's People Consultative Assembly Decree Number XVII/MPR/1998 concerning Human Rights and subsequently passed in Law Number 39 of 1999 concerning Human Rights (hereinafter referred to as the Human Rights Law). The provisions of the Human Rights Law define human rights as a set of rights attached to the essence and existence of human beings as God's creature and is a gift that must be respected, upheld and protected by the State, law and government, and everyone for the honor and protection of human dignity. ${ }^{48}$

Regulations regarding human rights can be seen in CHAPTER XA entitled Human Rights starting from Article 28A to Article 29 of the 1945 Constitution. Provisions concerning freedom from torture can be seen in Article 28G Paragraph (2) and Article 28I Paragraph (1). Article 28G Paragraph (2) of the 1945 Constitution which states that "every person has the right to be free from torture and treatment which demeans human dignity." Article 28I(1) states that "the right to life, the right not to be tortured, the right to have free will and conscience, religious rights, the right not to be enslaved, the right to be recognized as a person before the law, and the right not to be prosecuted on the basis of retroactive law, are human rights which cannot be reduced under any circumstances." Therefore, these rights are constitutional rights.

In line with the provisions of the 1945 Constitution, regulations concerning human rights have been regulated in Law No. 39 of 1999 concerning Human Rights. Article 2 states that "The Republic of Indonesia recognizes and upholds human rights and basic human freedoms as rights that are inherent in and inseparable from humans, which must be protected, respected, and upheld for increasing human dignity, prosperity, happiness, and intelligence and justice."

Article 4 asserts that "the right to life, the right not to be tortured, the right to personal freedom, free will and conscience, religious rights, the right not to be enslaved, the right to be recognized as a person and to be equal before the law, and the right not to prosecuted on the basis of retroactive law are human rights which cannot be reduced under any circumstances and by anyone."

\footnotetext{
47 Andi Hamzah, Sistem Pidana Dan Pemidanaan Indonesia, Dari Retribusi Ke Reformasi (Jakarta: PT. Pradnya Paramita, 1986).

48 The Law No. 39 of 1999 concerning Human Rights.
} 
Article 33(1) Law No. 39 of 1999 concerning Human Rights states that "everyone has the right to be free from torture, punishment, or cruel and inhuman treatment which degrades the dignity of humanity." Human rights are a gift given by God to every human being without exception. Therefore, no one has the right to rob the rights of another person. A person must respect other people's rights. A person cannot do whatever they want just because they have other people's rights since every right comes with responsibilities.

As the greatest gift from God, human rights are the rights belong to all humans. Humans become dignified because of those rights. Since human rights play a central role in the macrocosm and microcosm of the life of a nation, no one, including the rulers, can deprive someone of human rights. ${ }^{49}$

Human rights can be analyzed from the philosophical foundation contained in the Indonesian Criminal Procedural Code (KUHAP). Even though someone becomes a suspect or defendant of sexual violence against children, it is essential to consider the philosophical foundation of the KUHAP, as stated in a letter (a) of the Preamble, namely Pancasila, especially the principles concerning religiosity and humanity. Yahya Harahap stated that with the principle of religiosity, the KUHAP ${ }^{50}$ acknowledges that both law enforcement officers and suspects/defendants are:

a. Humans depend on God. Human beings who depend on God's will. All human beings without exception are God's creations that are born on the earth only because of God's will and grace;

b. Since all humans are God's creation and depend on God's will:

1) There is no fundamental difference between fellow human beings;

2) Both have the duty as human beings to develop and maintain their nature, dignity, and dignity as God's creature;

3) Every human being has rights which must be protected without exception;

4) Any function and duty carried out by every human being are only to fulfill the Mandate of God.

This philosophical foundation implies that the Indonesian Criminal Procedure Code requires the protection of human rights, including the offenders' rights and the victims' rights. The same thing also applies to the imposition of punishment on the offenders. The imposition of punishment must also consider the interests and protection of human rights for the victims. ${ }^{51}$

Indonesia is a country based on the rule of law and consequently must uphold a legal system that guarantees legal certainty and protects human rights. ${ }^{52}$ The State must guarantee the equality of each individual, including the individual's freedom to use his/her rights. It is a sine qua non, considering that a state based on the rule of law was born as a result of its individuals' struggle to free themselves from the authorities' arbitrary actions. Hence, the authorities must not act arbitrarily against individuals, and their power must also be limited. ${ }^{53}$ In a state based on the rule of law, everyone is treated equally before the law. This principle becomes a

49 Artidjo Alkostar, Korupsi Politik Di Negara Modern (Yogyakarta: FH UII Press, 2008).

50 Wanodyo Sulistyani, "The Admissibility of Scientific Expert Evidence Under Indonesian Criminal Justice System," Sriwijaya Law Review 2, no. 2019 (3AD): 152-61.

51 Lilik Mulyadi, Pembalikan Beban Pembuktian Tindak Pidana Korupsi (Bandung: Alumni, 2004).

52 Mulyadi.

53 Sudargo Gautama, Pengertian Tentang Negara Hukum (Bandung: Alumni, 1983). 
fundamental element of human rights. Related to this issue, Sudargo Gautama affirmed that in a state based on the rule of law, there is also restriction in addition to equality. The limits of this restriction can change depending on the circumstances. However, the means used to limit both interests are the law. Both the State and individuals are legal subjects who have rights and obligations. Therefore, in State law, individuals and the State has a balanced position and relationship, as both have rights and obligations that are protected by law. ${ }^{54}$

According to Soenawar Soekawati, the interpretation of the principle of equality before the law in Pancasila is different from the interpretation adopted by democratic countries in the West. Soekawati stated that Indonesia interprets equality and freedom as responsible freedom. It means that human rights are not absolute because in carrying out their rights, the citizens must follow the regulations to respect other people's rights and to create order in society. ${ }^{55}$

Therefore, as Moh. Mahfud MD said, the recognition and protection of human rights or citizens' rights by the constitution, both in the Preamble and the body of the 1945 Constitution, is proof that Indonesia is a country that stands on the principle of the rule of law. Recognition and protection of human rights in this concept does not mean that the State guarantees every citizen to be free in a legal environment under the provisions of the law, as stated by Frederich Julius Stahl. Human rights in this context mean the reality and legal awareness that exist in society, which must be upheld by every individual as the norm or the rule of law. ${ }^{56}$

The second principle, just and civilized humanity, can be studied from the perspective of human rights. This principle recognizes and declares that humans are created equal, but one person will have more gifts than the others based on his/her piety and appreciation of human values. Therefore, someone must not discriminate other people based on race/descent, social status, religion, and gender. This principle distinguishes humans from God's other creatures.

Criminal law is a legal field that is closely related to the second principle. So it is expected that both the actions and penalties should not deprive the people of just and civilized humanity. From the second principle, comes the concept that criminal law revolves more on human rights by recognizing the principle of balance and harmony.

The concept of balance as the content of Pancasila must be seen as an essential principle that surpasses liberalism, communism, and other concepts. ${ }^{57}$ The concept of balance, in this case, means creating a balance between the rights and the obligations of the offender and the victim. Discussion about human rights and criminal acts and the rights of the offenders and the victims always go hand in hand. Victims demand that the offenders must be responsible for their crimes. The offenders bear consequences of their actions by letting the State handle the matter through the criminal justice system, following the law.

The concept of balance, in this case, does not favor a particular party in the sense that it does not favor only the offenders' interests or only the victims' interests. Instead, it maintains both the offenders' and the victims' interests. In this case, the offenders of sexual violence against children have violated the victims' rights. Because the offenders have committed an act

54 Gautama.

55 O.C. Kaligis, Perlindungan Hukum Atas Hak Asasi Tersangka, Terdakwa Dan Terpidana (Bandung: PT. Alumni, 2006).

56 Abdul Ghofur Anshori \& Sobirin Malian, Membangun Hukum Indonesia: Pidato Pengukuhan Guru Besar Ilmu Hukum (Yogyakarta: Kreasi Total Media, 2008).

57 Zaidan, Menuju Pembaharuan Hukum Pidana. 
that breaks the laws and society's values, they reserve the right to receive sanctions following applicable regulations.

Ideally, as a state based on the rule of law, Indonesia should display a balance in upholding human rights in law enforcement, including toward the suspects, defendants, and victims. It is because, in every society, rights and obligations are inherent in the law. It means that rights and obligations are regulated by law so that individuals in a society can carry out their rights and obligations properly. For this reason, an individual's rights and obligations are interpreted as the rights and obligations of society. Likewise, human rights can be interpreted as society's human rights. So basically, discussing human rights is discussing these two aspects. These aspects, humanity, and democracy, are the soul of the law. ${ }^{58}$

Likewise, penalties imposed on the offenders of sexual violence against children must adhere to human rights. The additional penalty, namely the chemical castration, actually violates human rights. It also counts as torture, because the side effects of drugs used in chemical castration will affect many-body systems. The effects include the loss of male secondary hormone function, a decrease in testosterone, which affects the functions of other organs, such as muscle atrophy, bone loss, reduced blood cells, and impaired cognitive function. ${ }^{59}$ The torture of suspects or convicts is not in line with the principles of humanity and civilization. Hence, the laws in various countries prohibit these actions in various ways and reasons.

Torture of humans under any circumstances and in any form cannot be justified by legal order in a civilized society. For this reason, it is right to let the second principle of Pancasila determines the just and civilized humanity. Rawls believed that "the ideal structure of an ideal society is the basic structure of an indigenous society where basic rights, freedom, power, authority, opportunity, income, and welfare are fulfilled." Therefore policies for the prevention of sexual violence against children must be consistent with the principles of human rights and reflect the right practices so that the policy can run effectively.

\section{CONCLUSION}

As the philosophical foundation of the State, Pancasila has two meanings, both of which are inseparable. First, Pancasila is the only State ideology that acts as the primary foundation for the implementation of the State's core ideas. The focal point of these core ideas is a just and prosperous (material and spiritual) society, referring to just and civilized humanity, based on religiosity, humanity, unity, and democracy. These core ideas become the direction and the purpose of the State, formulated in the Preamble of the 1945 Constitution, especially in paragraph IV, the foundation, soul, and source of the spirit of State administration. Second, Pancasila is a moral foundation. The central point of State morality lies in religiosity that contains God's teachings and human values, which give birth to natural law and moral law as the rationale for regulating public order and the foundation of Indonesia's legal philosophy. If examined from the perspective of Indonesian political philosophy, chemical castration formulated in Article 81 Paragraph (7) is not in line with Pancasila, especially the first principle

58 Kaligis, Perlindungan Hukum Atas Hak Asasi Tersangka, Terdakwa Dan Terpidana.

59 "Tinjauan Etika Dokter Sebagai Eksekutor Hukuman Kebiri.," 2018, https://www.researchgate.net/ publication/325727634_Tinjauan_Etika_Dokter_sebagai_Eksekutor_Hukuman_Kebir. 
belief in One and Only God and the second principle just and civilized humanity. In criminal law, religiosity should give rise to principles that view humans as honorable beings compared to other creatures. Therefore, the content of criminal law must not conflict with humans' position as honorable beings. Furthermore, penalties for criminal acts must reflect respect to religiosity. Meanwhile, from the perspective of human rights, the second principle, just and civilized humanity, recognizes and declares that humans are created equal by God. However, one person will have more gifts compared to others considering their piety and appreciation of human values in general.

\section{REFERENCES}

Alkostar, Artidjo. Korupsi Politik Di Negara Modern. Yogyakarta: FH UII Press, 2008.

Fios, Frederikus. "Keadilan Hukum Jeremy Bentham Dan Relevansinya Bagi Praktik Hukum Kontemporer." Humaniora III, no. 1 (2012): 299-309.

Fuady, Munir Fuady and Sylvia Laura L. Hak Asasi Tersangka Pidana. Jakarta: Prenada Media Group, 2015.

Gautama, Sudargo. Pengertian Tentang Negara Hukum. Bandung: Alumni, 1983.

Ham, Komnas. "Komnas-Ham-Perppu-Tentang-Penghukuman-Kebiri-Untuk-TidakDiterbitkan," 2017. http://www.komnasham.go.id/kabar-latuharhary/komnas-ham-perpputentang-penghukuman-kebiri-untuk-tidak-diterbitkan.

Hamzah, Andi. Sistem Pidana Dan Pemidanaan Indonesia, Dari Retribusi Ke Reformasi. Jakarta: PT. Pradnya Paramita, 1986.

“International Covenant on Civil Political Rights," n.d.

Kaligis, O.C. Perlindungan Hukum Atas Hak Asasi Tersangka, Terdakwa Dan Terpidana. Bandung: PT. Alumni, 2006.

Kristian, Nyana Wangsa and. Hermeneutika Pancasila Orisinalitas Dan Bahasa Hukum Indonesia. Bandung: PT. Refika Aditama, 2015.

Lamintang, P.A.F., and Theo Lamintang. Hukum Penitensier Indonesia. Jakarta: Sinar Grafika, 2012.

Malian, Abdul Ghofur Anshori \& Sobirin. Membangun Hukum Indonesia: Pidato Pengukuhan Guru Besar Ilmu Hukum. Yogyakarta: Kreasi Total Media, 2008.

Mamuji, Soerjono Soekanto and Sri. Penelitian Hukum Normatif. Jakarta: Rajawali, 1985.

Mangunhardjana, A. Isme-Isme Dalam Etika Dari a Sampai Z. Yogyakarta: Kanisius, 1997.

Moh. Mahfud MD. Membangun Politik Hukum, Menegakkan Konstitusi. Jakarta: PT. Raja Grafindo, Persada, 2010.

Mulyadi, Lilik. Pembalikan Beban Pembuktian Tindak Pidana Korupsi. Bandung: Alumni, 2004.

Murray, John S. “California's Chemical Castration Law: A Model For Massachusetts?” 24, no. 279 (1998): 732.

Rahardjo, Satjipto. Hak Asasi Manusia Dalam Masyarakatnya. Bandung: Refika Aditama, 2005. 
Sahetapy, J. E. Suatu Studi Khusus Mengenai Ancaman Pidana Mati Terhadap Pembunuhan Berencana. Jakarta: CV. Rajawali, 1982.

Sholehuddin, M. Sistem Sanksi Dalam Hukum Pidana Ide Dasar Double Track System Dan Implementasinya. Jakarta: Raja Grapindo Persada, 2003.

Soekanto, Purnadi Pubacaraka and Soerjono. Perihal Kaedah Hukum. Bandung: Alumni, 1978.

Soekarno. Filsafat Pancasila Menurut Bung Karno. Yogyakarta: Media Presindo, 2006.

Stojanovsky, Vioslay. Surgical Castration Of Sex Offenders and 1st Legality: The Case Of the Czech Republic. Masarykiana Brunensis University, n.d.

Sulistyani, Wanodyo. "The Admissibility of Scientific Expert Evidence Under Indonesian Criminal Justice System.” Sriwijaya Law Review 2, no. 2019 (3AD): 152-61.

Supriyadi Widodo Eddyono, Dkk. Menguji Euforia Kebiri. Jakarta: ICJR Mappi FH UI, 2016.

The 1945 Constitution of the Republic of Indonesia (n.d.).

The Law No. 17 of 2016 Concenring Amendment to Law Number 10 of 1995 on Customs (n.d.).

The Law No. 39 of 1999 concerning Human Rights (n.d.).

“Tinjauan Etika Dokter Sebagai Eksekutor Hukuman Kebiri.," 2018. https://www.researchgate.net/ publication/325727634_Tinjauan_Etika_Dokter_sebagai_Eksekutor_Hukuman_Kebir.

Tongat. "Https://Ejournal.Fakultas Hukum Universitas Muhamadiyah Malang, Pancasila Sebagai Dasar Falsafah Negara Dan Makna Filosofisnya Dalam Pembaharuan Hukum Pidana Nasional," 2017.

Wahyuni, Fitri. "Hukuman Kebiri Terhadap Pelaku Tindak Pidana Pemerkosaan Anak Dan Kaitanannya Dengan Hak Asasi Manusia.” Jurnal Hukum Dan Peradilan 6, no. 2 (2017): 279-96.

Weiberger, Linda E., Sreenivasan Shoba, Thomas Garrick, and Handley Osran. "The Impact of Surgical Castration Risk among Sexually Violend Predatory Offenders.” The Journal of the American Academy of Psychiatry and the Law 33, no. 1 (2005): 16-36.

Zaidan, M. Ali. Menuju Pembaharuan Hukum Pidana. Jakarta: Sinar Grafika, 2015. 